Original Research Article

\title{
Evaluation of antidiabetic potential of hydroalcoholic extract of Annona squamosa (HAEAS) leaf in alloxan monohydrate induced diabetic Albino rats
}

\author{
Ahmed S. K. ${ }^{1}$, Naveen Alasyam ${ }^{2}$, Chakrapani Cheekavolu ${ }^{3 *}$, Sunil M. ${ }^{4}$
}

${ }^{1}$ Department of Pharmacology, Shadan Institute of Medical Sciences (SIMS), Hyderabad, Telangana, India

${ }^{2}$ Department of Pharmacology, Vishnu Dental College, Vishnupur, Bhimavaram, West Godavari, Andhra Pradesh, India ${ }^{3}$ Department of Pharmacology, Kerala Medical College and Hospital, Mangode, Palakkad, Kerala, India

${ }^{4}$ Department of Pharmacology, Maheshwara Medical College and Hospital, Isnapur, Patancheru, Medak, Telangana, India

Received: 19 October 2017

Revised: 31 October 2017

Accepted: 09 December 2017

*Correspondence to:

Dr. Chakrapani Cheekavolu, Email: chakri14783@gmail.com

Copyright: (C) the author(s), publisher and licensee Medip Academy. This is an openaccess article distributed under the terms of the Creative Commons Attribution NonCommercial License, which permits unrestricted noncommercial use, distribution, and reproduction in any medium, provided the original work is properly cited.

\begin{abstract}
Background: Diabetes is almost growing health concern worldwide and now emerging as an epidemic world over. Recently, full attention is being paid to the study of natural products as potential antidiabetics. Objective of the study was to evaluate the antidiabetic effect of hydroalcoholic leaf extract of Annona squamosa (HAEAS) plant in alloxan monohydrate induced diabetic albino rats. Methods: Almost a 30 Albino rats with 150- 200 grams weight were weighed and grouped into 5 equal groups taking 6 rats in every group. Group A served as normal control, Group B as diabetic control, received alloxan monnohydrate. Group C and D was received alloxan + HAEAS suspension at 350 and $700 \mathrm{mg} / \mathrm{kg}$ doses orally respectively, Group $\mathrm{E}$ was given alloxan + standard drug (Glibenclamide $5 \mathrm{mg} / \mathrm{kg}$ ) suspension for 28 successive days and the effect of HAEAS on blood sugar(BS) levels was measured at regular intervals. At the end portion of this investigational research study samples of blood were collected from all rats on 0day (initial), after $72 \mathrm{hrs}$ and after 28th day (29thday) of given test drug HAEAS treatment for biochemical estimation of BS and the BS values were observed.

Results: The present research study revealed that HAEAS leaves has antidiabetic effect against alloxan monohydrate induced diabetic rats on i.p. alloxan injection at $150 \mathrm{mg} / \mathrm{kg}$. b.w. and confirms that on i.p. alloxan injection causes a significant rise off BS in untreated albino rats when compared to control group. Diabetic rats treatment with HAEAS leaves for 28 days caused dose a dependent fall in BS values. Glibenclamide treated diabetic rats also showed a significant $(\mathrm{P}<0.00)$ fall in BS content after 28 days of treatment.

Conclusions: This research study confirms that HAEAS leaves has shown significant antidiabetic effect at 350 and $700 \mathrm{mg} / \mathrm{kg}$. b.w. doses in alloxan monohydrate induced diabetic rats.
\end{abstract}

Keywords: Antidiabetic property, Albino rats, Blood sugar, Glibenclamide, HAEAS

\section{INTRODUCTION}

Almost most all Medicinal plants has been abundantly used everywhere in many countries to control diabetes mellitus (DM). The hypoglycemic action of these plants is still being in study state/study level. ${ }^{1}$ Diabetes is fairly a chronic metabolic disorder of carbohydrate, protein and fat metabolism which is characterized by elevation/enhanced 
levels of both fasting and post prandial BS which is usually resulted from either insufficiency of insulin or dysfunction of insulin. ${ }^{2}$ Annona squamosa belongs to the family of Annonaceae and is known as "sitaphal" in Hindi and is a plant of West- Indies country and is cultivated now throughout the India at present. ${ }^{3}$ The Annona fruits are eaten fresh actually. This plant leaves have been used as a styptic, anthelmintic and. Insecticide. ${ }^{4}$ Unripe and dried fruits works as a antidysentric and bark of Annona is used as a tonic and also as a powerful astringent and vermifuge. ${ }^{4}$ Powdered seeds of Annona used to kill headlice. ${ }^{4}$ The plant of Annona is reported to have phenolic compounds, glycosides, proteins, flavonoids and tannins etc. in it. ${ }^{5}$ Flavonoids of this plant are known to possess the antidiabetic activity. ${ }^{6}$ Annona leaves Phytochemical compound screening has revealed that it has flavonoids in it. $^{7}$ Hence, the exact aim of this present research study is to evaluate the antidiabetic effcet of Annona squamosa (AS) leaves hydroalcoholic extract in albino rat model.

\section{METHODS}

\section{Drugs and chemicals}

Alloxan monohydrate (Sigma Aldrich Chemicals St.louis, USA.), Tab glibenclamide, 5mg (Aventis Pharma Ltd, Ankles war), Diagnostic Kits (Roche, Mumbai), Methanol.

\section{Experimental animals}

Both sexes of the rats (Albino rats) with a weight between $150 \mathrm{gm}-200 \mathrm{gm}$ were actually used in this experiment. Albino rats were housed actually in polypropylene cages and were grouped in to 5 groups, each group contains 6 rats and were kept at a controlled room temperature of $25 \pm 2^{\circ} \mathrm{C}$, and a relative humidity of $55 \%$ and $12 \mathrm{hrs}$. light: dark cycle and were fed with the supplied standard food pellet diet and water ad libitum during this experiment. Prior to this experiment the rats were almost fasted for a exact time period of $12 \mathrm{hrs}$ with water ad libitum given and weighed. All the study protocols of this research study were approved by CPCSEA (Committee for the Purpose of Control and Supervision of Experiments on Animals) and were cleared by Institutional Animal Ethics Committee (IAEC) clearance at Mamata Medical College (MMC), Khammam of Telangana state.

\section{Plant material and plant extract preparation}

Annona plant leaves were collected from local places near Khammam city at rotary nagar exactly in OctoberNovember and were authenticated by Assist. Professor and Head, Botany Department, Govt. SRBJNR PG College, Khammam. Extract was prepared by using the cold maceration method. Annona Leaves were shade dried at a room temperature for almost one week. These dried Annona plant leaves were crushed in the form of fined powder (Annona squamosa leaves powder) by using a grinder (mixer grinder). This fine AS leaf powder was then weighed and used for extraction using $70 \%$ of alcohol(methanol) as a solvent. The solvent is evaporated then at the room temperature to get a reddish brownish coloured extract. This obtained extract was stored at a temperature of $2-8^{\circ} \mathrm{C}$ till further any other use.

\section{Induction of diabetes in rats}

Rats were used in this study were almost fasted overnight and the blood was withdrawn from tail vein of the rats of all each rat group before the treatment day (0(initial) day) and after a exact 28 days of (on 29th day) treatment. Serum of collected blood samples from the rats was completely separated by the process of centrifugation and used for biochemical estimation like BS. ${ }^{9}$ Before Diabetes induction rats were almost fasted upto an $18 \mathrm{hrs}$ period. ${ }^{10}$ Alloxan monohydrate single dose (150 mg/kg, b.w.) i.p. was dissolved in the normal saline and was used for type 2 diabetes induction in rats after an overnight fasting. After $1 \mathrm{hr}$ of the administration of alloxan, the experimental animals (rats) were fed with supplied standard food pellet diet and water ad libitum during this experimental procedure. The rats were stabilized for a week and animals showing a BS level of more than 200mg/dL (>200 mg/dL) were selected for this experimental research study.

\section{Experimental study design}

Albino Rats were completely divided in 5 groups whereas group 1 was remained non-diabetic and group 2 consist of diabetic and group 3 and 4 consist of diabetic + treated:

- Group I: Rats (normal control) received vehicle $(1 \mathrm{ml} / \mathrm{kg} 0.5 \% \mathrm{CMC})$ orally for a exact 28 days period.

- Group II: Rats (diabetic control) received alloxan monohydrate (Sigma Ltd., USA) single dose (150mg/kg, b.w.) i.p. dissolved in NS (normal saline) after full night fasting was used for induction of type 2 diabetes in rats.

- Group III: Rats received i.p. alloxan single dose + HAEAS suspension at $350 \mathrm{mg} / \mathrm{kg}$ b.w. dose in $0.5 \%$ CMC orally for an exact 28 days period.

- $\quad$ Group IV: Rats received i.p alloxan single dose + HAEAS suspension at $700 \mathrm{mg} / \mathrm{kg}$ b.w. dose orally for an exact 28 days period.

- Group V: Rats received alloxan single dose (150 $\mathrm{mg} / \mathrm{kg}$, b.w.) i.p. plus Glibenclamide ( $5 \mathrm{mg} / \mathrm{kg}$ b.w.) suspension orally for 28 days period.

After 30 minutes of the treatment, each group rats were given glucose $(5 \mathrm{gm} / \mathrm{kg})$ orally in distilled water and blood samples were collected from all groups on 0day (initial), after $72 \mathrm{hrs}$ and after 28 day (29thday) of given test drug HAEAS treatment for the BS estimation and BS values were observed. ${ }^{12}$

\section{Statistical data analysis}

Results of BS estimation are reported as mean \pm SD of six rats in each rat group. The data were subjected to ANOVA 
(one-way analysis of variance) for multiple comparisons followed by Dunnett's test was applied for determining statistical significance of difference in the sugar levels. $\mathrm{P}<0.05$ were considered as statistically significant. ${ }^{11}$

\section{RESULTS}

The present research study has revealed that HAEAS leaves has antidiabetic activity against the alloxan induced diabetic albino rats on i.p. alloxan injection at $150 \mathrm{mg} / \mathrm{kg}$.b.w. dose and confirms that on i.p. alloxan injection alloxan causes a significant rise off BS content in untreated (diabetic rat group) albino rats when compared to control group was shown in (Table 1). ${ }^{8}$

Treatment of diabetic rats with HAEAS leaves for exactly 28 days actually caused a dose dependent fall in the BS levels. Glibenclamide treated rats with diabetes was also showed a significant $(\mathrm{P}<0.00)$ fall in the BS content after exacting 28 days of treatment as shown in (Table 1 ).

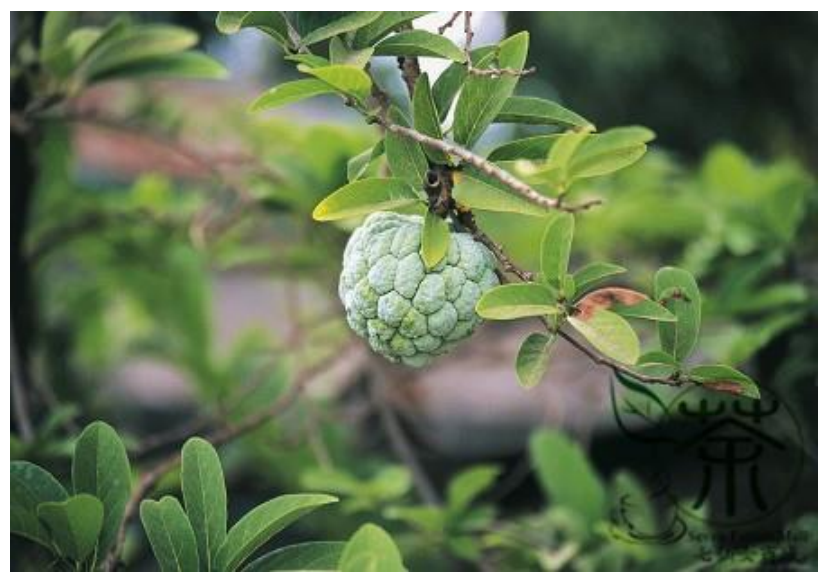

Figure 1: Annona squamosa leaves.

Table 1: Effect of HAEAS in alloxan monohydrate induced diabetic albino rats on FBS levels.

\begin{tabular}{|llll|}
\hline Group treatment & \multicolumn{3}{l|}{ Fasting blood sugar (mg/dl) } \\
\hline & 0 day (initial) & After 72 hours & $2^{\text {th }}$ day (final) \\
\hline Normal control 0.5\% CMC 1 ml/kg/day orally & $97.3 \pm 5.0$ & $99.5 \pm 3.2$ & $96.5 \pm 5.3$ \\
\hline Diabetic control alloxan (150 mg/kg) in a single i.p. dose & $96.66 \pm 7.8$ & $284.8 \pm 5.1$ & $276.3 \pm 4.5$ \\
\hline $\begin{array}{l}\text { Diabetic+AS leaves hydroalcoholic extract (350mg/kg/day) } \\
\text { orally }\end{array}$ & $99.8 \pm 6.4$ & $282.2 \pm 6.0^{*}$ & $196.8 \pm 2.5^{* *}$ \\
\hline $\begin{array}{l}\text { Diabetic+AS leaves hydroalcoholic extract (700mg/kg/day) } \\
\text { orally }\end{array}$ & $99.83 \pm 3.1$ & $276.8 \pm 3.3^{*}$ & $180.5 \pm 6^{* *}$ \\
\hline Diabetic+glibenclamide 5mg/kg/day orally & $97.67 \pm 4.3$ & $267.2 \pm 6.1^{*}$ & $145 \pm 3.8^{* *}$ \\
\hline
\end{tabular}

All values are expressed in Mean \pm SD. Analyzed by one way ANOVA followed by Dunnet's test for multiple comparison tests. $*=p<0.05$ when compared to the normal control group (significant $p$ value)

$* *=p<0.00$ when compared to diabetic control group (Highly significant $\mathrm{p}$ value)

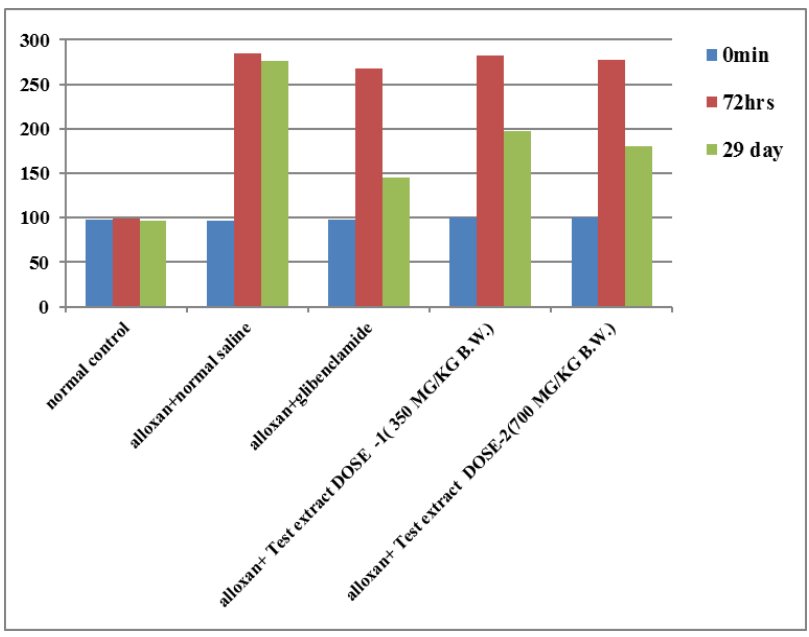

Figure 2: Effect of AS leaves hydroalcoholic extract on FBS levels in alloxan monohydrate induced diabetic albino rats.

\section{DISCUSSION}

Chemically, alloxan (2,4,5,6 tetraoxypyrimidine) is an oxygenated derivative of pyrimidine and is a cyclic analog of urea which was reported to cause/develop permanent diabetes in most of the experimental animals such as rats and rabbits. It is a most popular diabetogenic agent which is used to induce type- 2 diabetes in the experimental animals (chemical induction of diabetes/experimental diabetes induction by chemicals. ${ }^{14,15}$ One of the most powerful methods of experimental diabetes induction is chemical induction of diabetes by Alloxan. ${ }^{16}$ In the present research study, alloxan caused a noticeable/prominent rise off FBS levels in diabetic rats. As the alloxan monohydrate is an extremely reactive/full reactive molecule which is almost readily reduced to diuleric acid, which is then gets auto-oxidized back to alloxan which ultimately results in the free radicals production/generation which ultimately damaged the $\beta$ - cells of pancreatic islets DNA and thereby cause cell death at the end. ${ }^{15}$ 
In addition, Alloxan monohydrate has also been widely used for the induction of experimental diabetes in the experimental animals like rabbits, rats, dogs and mice with a different disease severity grades by varying the alloxan dose used. ${ }^{16,17}$

As the alloxan monohydrate has also been widely accepted diabetic inducer of which alloxan selectively crash/damage the insulin-producing $\beta$-cells found usually in the pancreas, therefore it is used for diabetes induction in most of the laboratory animals. The toxic action of alloxan monohydrate is that it acts on pancreatic $\beta$-cells which involve oxidation of essential sulphydryl (-SH groups), inhibition of glucokinase enzyme, free radicals' generation and annoyances/interference in the intracellular $\mathrm{Ca}^{2+}$ (calcium) homeostasis. ${ }^{18-20}$

Diabetic rat's treatment with the Annona leaf extract at 350 and $700 \mathrm{mg} / \mathrm{kg}$ doses for an exact 28 days' time period produced a significant fall in the FBS in a dose dependent manner when we compared to diabetic control group. Most of the studies of Annona on diabetes were revealed that there is a remarkable improvement in the condition of damaged $\beta$ - cells in histological study of the pancreas of most of diabetic albino rats treated with annona leaf extract. However, the Annona squamosa leaves hydroalcoholic extract (HAEAS) did not restore the disturbed biochemical parameter like BS content to normal value in diabetic rats. ${ }^{12}$ Hence, the extract can be used in a combination with the other established anti-diabetic drugs or herbal formulations for more better effective outcomes.

\section{CONCLUSION}

In this present research study, our experimental data finding clearly revealed that the test extract of our study, i.e. hydroalcoholic Annona squamosa leaves extract (HAEAS) at some doses of $350 \mathrm{mg} / \mathrm{kg}$ and $700 \mathrm{mg} / \mathrm{kg}$ b.w. possess potent antidiabetic activity. Thus, as a potential antidiabetic drug/agent these Annona leaves can be used. It could be a novel antidiabetic drug and also a dietary adjunct for the DM management and its complications. However, the exact mechanism of the antidiabetic property of Annona leaves extract is unknown. However, further confirmatory studies are still required to identify the probable mechanism of action to establish its antidiabetic action.

\section{ACKNOWLEDGEMENTS}

Authors would like to thank to The Chairman, Mamata Medical College (MMC), Khammam, Telangana state, for his guidance and encouragement. whose spacious heart actually cheered the efforts of authors to process this research study successfully to complete the framed task. Also authors extend their special thanks to the Secretary, Principal and Head of the pharmacology department and the Staff members of the Mamata Medical College.
Funding: No funding sources

Conflict of interest: None declared

Ethical approval: The study was approved by the Institutional Animal Ethics Committee

\section{REFERENCES}

1. Tenpe CR, Yeole PG. Comparative evaluation of antidiabetic activity of some marketed polyherbal formulation in alloxan induced diabetic rats. $\mathrm{J}$ of Pharma Tech Research. 2009;1(1):43-9.

2. Modak M, Dixit P, Londhe J, Ghaskadbi S, Devasagayam A, Paul T. Indian Herbs and Herbal Drugs for the treatment of Diabetes. J of Clin. Biochemistry. 2007;40(3):163-73.

3. Porwal M, Sharma K, Malik P. Anticovulsant Effect of Annona squamosa Linn. Leaves in Mice. Pharmacologyoline. 2011;2:44-52.

4. Shah R. Pharmacognosy and Pharmacology of Annona squamosa: A review. Int. J of Pharmacy and Life Sciences. 2011;2(10):1183-9.

5. Pandey N, Barve D. Phytochemical and Pharmacological Review on Annona squamosa Linn. Int. J of Res in Pha and Biom Sci. 2011;2(4):1404-8.

6. Lukacinova A, Mojzis J, Benacka R, Keller J, Kurila P, Vasko L, et al. Preventive Effects of Flavonoids on Alloxan-Induced Diabetes Mellitus Rats. Acta vet. Brno. 2008;77:175-82.

7. Vanitha V, Umadevi KJ, Vijaylakshmi K. Determination of Bioactive Components of Annona squamosa L. Leaf by GC-MS Analysis. Int. J of Pharma Sci and Drug Res. 2011;3(4):309-12.

8. Gulfraz M, Ahmed A, Asad MJ, Sadiq A, Afzal U, Anwar P. Antidiabeti activities of Leavesand root extracts of Justica adhatoda Linn. against Alloxan induced diabetes in rats. African $\mathrm{J}$ of Biot. 2011;10(32):6101-6.

9. Hugo WB, Russel AD. Pharmaceutical Microbiology, $3^{\text {rd }}$ Edition, Blackwell science Publication; 1984:179200.

10. Rathnakar UP, Hashim SD, Pemminatti S, Shenoy A, Gopalkrishna HN, Siddique F. Hypoglycemic activity of a polyherbal product in alloxan induced diabetic rats. DrugInvention Today. 2011;3(3):1-2.

11. Sisodia SS, Bhatnagar M. Hepatoprotective activity of Eugenia jambolana Lam. in Carbon tetrachloride treated rats. Ind. J of Pharmacology. 2009;41(1):23-7.

12. Tomar RS, Sisodia SS. Antidiabetic activity of Annona squamosa Linn. in alloxan induced diabetic rats. International Journal ofz Green Pharmacy. [serialonline] Available at: http://dx.doi.org/10.22377/ijgp.v8i4.419,2014;8.No.4 2014:240-241.

13. Tomar RS, Sisodia SS. Antidiabetic Activity of Annona squamosa L. In Experimental Induced Diabetic Rats. International Journal of Pharmaceutical and Biological Archives. 2012;3(6):1492-5.

14. Viana GS, Medeiros AC, Lacerda AM, Leal LK, Vale TG, Matos FJ. Hypoglycemic and anti-lipemic effects 
of the aqueous extract from Cissus sicyoides. BMC Pharmacol. 2004;8:4-9.

15. Gupta SK. Antidiabetic Agents. In: Drug Screening Methods. $2^{\text {nd }}$ Edition. New Delhi: Jaypee Brothers Medical Publishers; 2009:590-591.

16. Etuk EU. Animals models for studying diabetes mellitus. Agric Biol J N Am. 2010;1:130-4.

17. Iranloye BO, Arikawe AP, Rotimi G, Sogbade AO. Anti-diabetic and antioxidant effects of Zingiber Officinale on alloxan-induced and insulin-resistant diabetic male rats. Niger J Physiol Sci. 2011;26:89-96.

18. Dunn JS, Sheehan HL, Mclethie NGB. Necrosis of islets of Langerhans produced experimentally. Lancet. $1943 ; 1 ; 484-7$.
19. Szkudelski T. The Mechanism of Alloxan and Streptozotocin Action in B Cells of the Rat Pancreas Physiol Res. 2001;50:536-46.

20. Dhanesha N, Joharapurkar A, Shah G, Dhote V, Kshirsagar S, Bahekar R, Jain M. Exendin- 4 activates glucokinase. J Diabetes. 2012.

Cite this article as: Ahmed SK, Alasyam N, Cheekavolu C, Sunil M. Evaluation of antidiabetic potential of hydroalcoholic extract of Annona squamosa (HAEAS) leaf in alloxan monohydrate induced diabetic Albino rats. Int J Basic Clin Pharmacol 2018;7:179-83. 